\title{
The Quality Improvement of Indonesian Konjac Chips (Amorphophallus Muelleri Blume) through Drying Methods and Sodium Metabisulphite Soaking
}

\author{
Kisroh Dwiyono ${ }^{1} \&$ Maman A. Djauhari ${ }^{2}$ \\ ${ }^{1}$ Faculty of Agriculture, Universitas Nasional, Jalan Sawomanila 61, Jakarta 12520, Indonesia \\ ${ }^{2}$ Graduate School, Institut Pendidikan Indonesia, Jalan Terusan Pahlawan 32, Garut 44151, Indonesia \& \\ Universitas Negeri Jakarta, Jalan Rawamangun Muka, Jakarta 13220, Indonesia. E-mail: \\ maman_djauhari@yahoo.com \\ Correspondence: Kisroh Dwiyono, Faculty of Agriculture, Universitas Nasional, Jalan Sawomanila 61, Jakarta \\ 12520, Indonesia. E-mail: kisrohdwiyono@gmail.com
}

Received: July 4, 2019

doi:10.5539/mas.v13n9p107
Accepted: August 27, 2019

URL: https://doi.org/10.5539/mas.v13n9p107
Online Published: August 30, 2019

\begin{abstract}
Amorphophallus muelleri Blume (Indonesian konjac) is an annual herbaceous wild plant growing in Indonesia. It produces glucomannan, i.e., a polysaccharide hydrocolloid compound that has many benefits in various fields of industry and has high economic value. To obtain this compound, Indonesian konjac tuber has to be processed into chips, ground, and separated from the other components such as fiber and starch. The problem encountered in producing glucomannan is to find a drying method which may optimally decrease the water content in chips with higher drying rate to produce good quality of the chips. This paper proposes a drying method and to study its effect on the quality of Indonesian konjac chips. For this purpose, we consider these two main treatments; (i) soaking in sodium metabisulphite solution in pre-drying process, and (ii) drying using oven and direct sun light. Thus, we work with four combinations of treatments and then we compare the effect of each combination on the quality characteristics of the chips. The experiment shows that the combination of oven drying method and soaking method produces the best results. In this experiment, we use $1500 \mathrm{ppm}$ of that solution and 10 minutes of soaking. According to our knowledge, these is an unprecedented experiment and thus the results will hopefully be a significant contribution to the literature of food engineering.
\end{abstract}

Keywords: chips quality, drying rate, konjac chips, sodium metabisulphite, water content

\section{Introduction}

\subsection{Generality}

Indonesian konjac (IK, in brief) is a tuber crops from Araceae family and monocotyledoneae class. It grows in wild area (Figure 1A) in various parts of Indonesia such as Sumatra, Java, Flores, East Nusa Tenggara, and West Nusa Tenggara (Jansen \& Hetterscheid, 1996). Interestingly, its domestication (Figure 1B) can be found in Java where it is widely grown by farmers in the surrounding forest and their yards. This plant produces tubers (Figure 1C) containing glucomannan which has many benefits in various industries such as food industry (e.g., shirataki and konyaku) and pharmaceutical industry (e.g., medication for diabetes mellitus, cancer, and cholesterol). Many other benefits, such as Wardhani, et al. (2017) and Zhang, et al. (2010) have remarked, are to strengthening woven textile, media for microbe cultures, and edible film. It can also be used as anti-human immunodeficiency virus (HIV) compound is discussed in (Bo et al, 2013). This shows that IK processing to produce high quality IK flour is very important. In this process, the two most important steps are soaking and drying methods. The details of these methods will be the main discussion in this paper. 


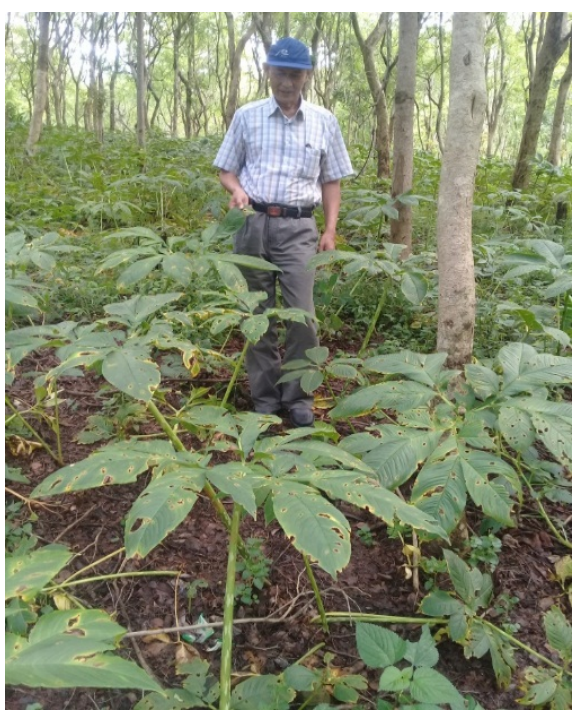

(A)

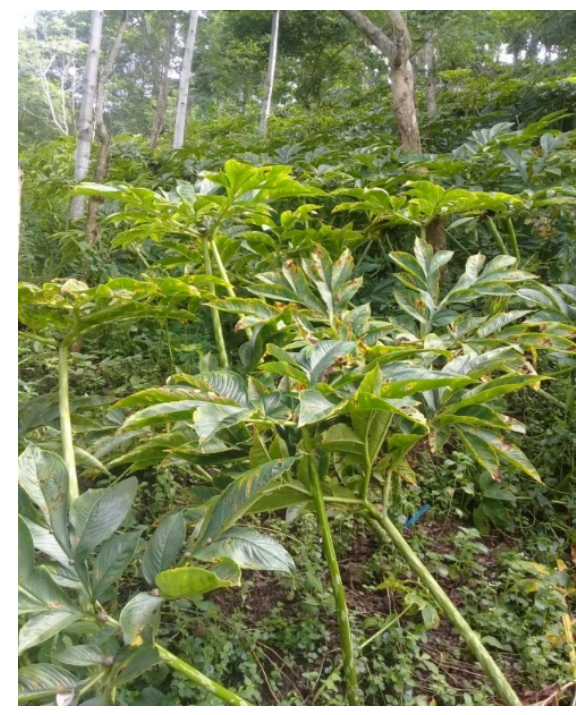

(B)

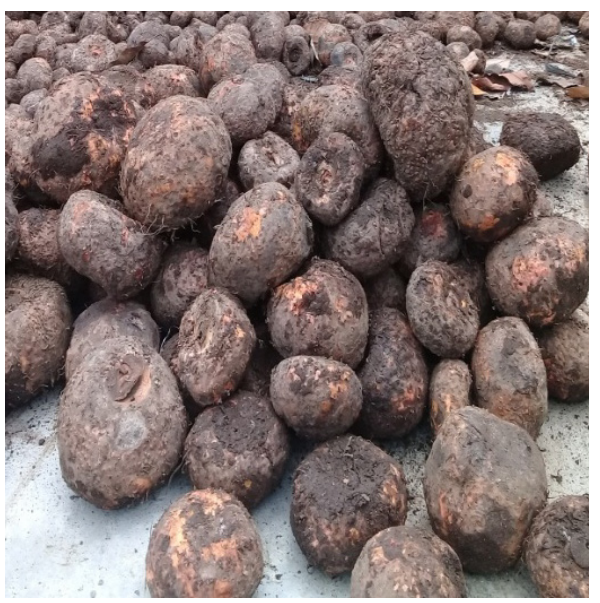

(C)

Figure 1. IK plant in wild area (A) and in domestication area (B) and IK tuber (C)

\subsection{Research Problems}

The three quality characteristics of IK chips are slice thickness, water content, and whiteness color. According to our previous study, see Dwiyono et al. (2014), dried chips produced by farmers still have diverse slice thickness, high water content, and relatively unattractive white color. This shows that the quality of dried chips produced by farmers cannot be expected as high. Therefore, a new IK tuber processing is required. This is the general issue that will be discussed in the rest of the paper.

The first step in producing high quality IK flour is to handle carefully the fresh harvested IK tuber. As we know, the water content in IK tuber is high. Consequently, it will cause the rapid growth of mold. Thus, if the water content is not immediately reduced, IK tuber will immediately spoiled and thus useless. To decrease the water content and prevent mold growth, IK tuber is processed into dried chips. Besides this advantage of dried chips, many other advantages are to extend the self-life, increase food safety, reduce bulkiness, increase sale value, reduce shrinkage, make its transportation easy, and to prevent deterioration in the chemical composition of the material. Thus, the important of dried chips quality. In the literature, the criteria of drie chips are as follows. Its thickness must be homogenous ranging from around 4 to $6 \mathrm{~mm}$ and the whiteness must be more than $61 \%$ 
(Dwiyono et al., 2014). Meanwhile, according to Indonesian National Standard, the water content must be less than $12 \%$.

We summarize that the problems encountered in this research consist of three folds, i.e., to produce homogenous thickness of chips, to increase the whiteness of the chips, and to reduce the water content.

\subsection{Objectives of the Study}

The first objective of this research is to produce homogenous thickness of chips. If the farmer uses traditional method by using manual method, here we use automatic machine. The second objective is to increase the whiteness of the chips, we use a new soaking treatment which consists of $1500 \mathrm{ppm}$ sodium metabisulphite solution during 15 minutes followed by washing and drying process. Thus, soaking treatment is taken place during pre-drying process. The third or last objective is reduce the water content of hips. In this regards we use a new drying method at $50^{\circ} \mathrm{C}$ during 36 hours.

Reducing water content though drying process is meant preserving food by reducing the water activity and microorganisms as well as minimizing physical and chemical changes during storage. Dying treatment is also to reduce the volume and weight during packaging, storage, and transportation (Doymaz, 2008). Doymaz has also remarked that to speed up the drying process with high drying rate, materials are usually cut into a smaller size. However, drying rate is influenced by both internal factor (e.g., shape, size, and material composition) and external factor (e.g., temperature, humidity, and air flow rate). These factors are the main consideration in this paper.

Compared with the traditional sun drying (SD) method, which is widely practiced, SD depends very much on weather and environment condition. As a consequence, it might produce chips which most probably have higher water content and, at the end, this will result a biochemical reaction on their cellular structure leading to fast mold growth. This method is commonly practiced in tropical countries, including Indonesia. However, some disadvantages cannot be avoided. For example,(i) contamination from insects, mold, or dust, (ii) the quality could be damaged due to rain fall, and (iii) time consuming. In short, SD method produces dried chips with low quality. The effect of drying process to the quality of chips of different material has been the active research for many years such as discussed in Chouicha et al. (2013), Ahn et al. (2014), Santos et al. (2015), Pornpraipech et al. (2017), Carneiro et al. (2018) and Nazamani et al. (2019).

These are the objectives of this research. In the next section we begin our discussion with literature review in Section 2 followed by the methodology of this research in Section 3 which includes chemical treatment, drying methods, and experimental design. The results will be reported and discussed in the fourth section. This paper ends with a conclusion in Section 5; the last section.

\section{Literature Review}

As we have mentioned earlier, konjak tuber has many benefits in various industries. For many decades its benefit for food industry and pharmaceutical industry is very well-known. Recently, Wardhani, et al. (2017) and Zhang, et al. (2010) have remarked its use in textile industry and microbe culture development. A more surprising discussion is addressed in (Bo et al, 2013) where chemical compound in konjak tuber can be used as anti-human immunodeficiency virus (HIV). Due to that special benefit, research on how to produce high quality of konjak flour is very active. In this production process of flour, slicing technique to have homogenous thickness of chips which could increase the drying rate, soaking in chemical solution during pre-drying treatment to increase the whiteness level and drying process to reduce the water content, are the three most important steps.

Regarding the thickness and the whiteness level of chips, Dwiyono et al. (2014) suggest the thickness is around 4 to $6 \mathrm{~mm}$ while the whiteness must be more than $61 \%$. On the other hand, as required by Indonesian National Standard, the water content must be less than $12 \%$. To ensure that the thickness is homogenous, there is no other way than to use mechanical or electrical devices instead of using traditional (manual) slicing practice. Therefore, this problem is easy to handle, researchers are more interested in the last two problems. To increase the whiteness level, in this research we conduct the common practice of soaking treatment in sodium metabisulphate solution as presented and discussed in (Slattery, 2019), (Buckman et al., 2015) and (S.Maathumai et al., 2018). The concentration of the solution is kept $1500 \mathrm{ppm}$ while the duration time of soaking is 15 minutes instead of 10 minutes that usually practiced by the previous researchers.

Meanwhile, the importance of drying treatment has been presented and discussed in many articles. Very recent discussions of this treatment can be found, for example, in (Chouicha et al., 2013), (Ahn et al., 2014), (Santos et al., 2015), (Pornpraipechet al., 2018), (Carneiro et al., 2018) and (Nizamani et al., 2019). In this present research, 
drying process is conducted using oven at $50^{\circ} \mathrm{C}$ with relative humidity of $34 \%$, and air velocity of $5.4 \mathrm{~m}^{2} / \mathrm{sec}$. In summary, the state-of-the-art of this research is presented in Table 1.

Table 1. Characteristics of experiment

\begin{tabular}{|c|c|c|c|}
\hline No. & Characteristic & Common practice & Our experiment \\
\hline 1 & Thickness of chips & No standard & $4-6 \mathrm{~mm}$ \\
\hline 2 & Slicing technique & Manual & Mechanical/electrical \\
\hline 3 & Soaking duration & 10 minutes & 15 minutes \\
\hline 4 & $\begin{array}{l}\text { Concentration of sodium metabisulphite } \\
\text { solution }\end{array}$ & $1500 \mathrm{ppm}$ & $1500 \mathrm{ppm}$ \\
\hline 5 & Whiteness & Less than $61 \%$ & $61 \%$ \\
\hline 6 & Water content & Less than $12 \%$ & Less than $12 \%$ \\
\hline 7 & Temperature of oven & Less than $50^{\circ} \mathrm{C}$ & $50{ }^{\circ} \mathrm{C}$ \\
\hline 8 & Relative huminity in laboratory & N/A & $34 \%$ \\
\hline 9 & Air velocity & N/A & $5.4 \mathrm{~m}^{2} / \mathrm{sec}$ \\
\hline
\end{tabular}

Based on these characteristics, in the rest of this paper a report of research methodology that we conduct and its results will be presented and discussed.

\section{Methodology}

Materials used in this research are IK dried chips produced from tubers of the plants of aged 2 to 3 years old. They are purchased from the farmers in the IK production center in Saradan, District of Madiun, East Java, Indonesia. Sodium metabisulphite was purchased from a local store in the city of Bogor where our working laboratory at Bogor Agricultural University is located. The equipment used in this research consists of drying oven Memmert D-06062, manual bulbs chopper, the analytical balance of Sartorius with a precision of $0.0001 \mathrm{~g}$, vernier caliper Tricle Brand 0-150 mm, Kett Whiteness meter C-100, and anemometer Lutron LM-8000 type.

\subsection{Drying Method}

There are eleven characteristics of IK dried chips that we analyzed. They are water content (Adegunwa et al, 2011), calcium oxalate, ash, fiber, fat, protein, starch, (Oke and Bolarinwa, 2012), glucomannan, whiteness, $\mathrm{SO}_{2}$ residue (Haryani, 2017), and total plate colony (Brugger et al, 2012). The analysis is carred out based on two groups of sample. Each sample consists of 10 chips or $200 \mathrm{~g}$. One group was soaked into sodium metabisulphite at $1500 \mathrm{ppm}$ for 15 minutes, while the other group was not soaked. Each group was divided into two parts with the same weight of $100 \mathrm{~g}$. One subgroup was dried in a drying oven at a temperature of $50^{\circ} \mathrm{C}$, relative humidity (RH) of $34 \%$, and air velocity of $5.4 \mathrm{~m}^{2} / \mathrm{sec}$. The second subgroup was dried under direct sunlight at a temperature of $32^{\circ}-42^{\circ} \mathrm{C}$, RH of $32 \%-38 \%$, and air velocity of $2.5-3.0 \mathrm{~m} / \mathrm{sec}$. Experiments were carried out every hour during the first six hours, every two hours during the second six hours, and every four hours during the last 24 hours of observation. The total drying time was 36 hours. The observed parameters are (i) the decrease of water content to a certain level using gravimetric method, (ii) the rate of drying, and (iii) chip characteristics. This flowchart of this experiment is illustrated in Figure 2. 


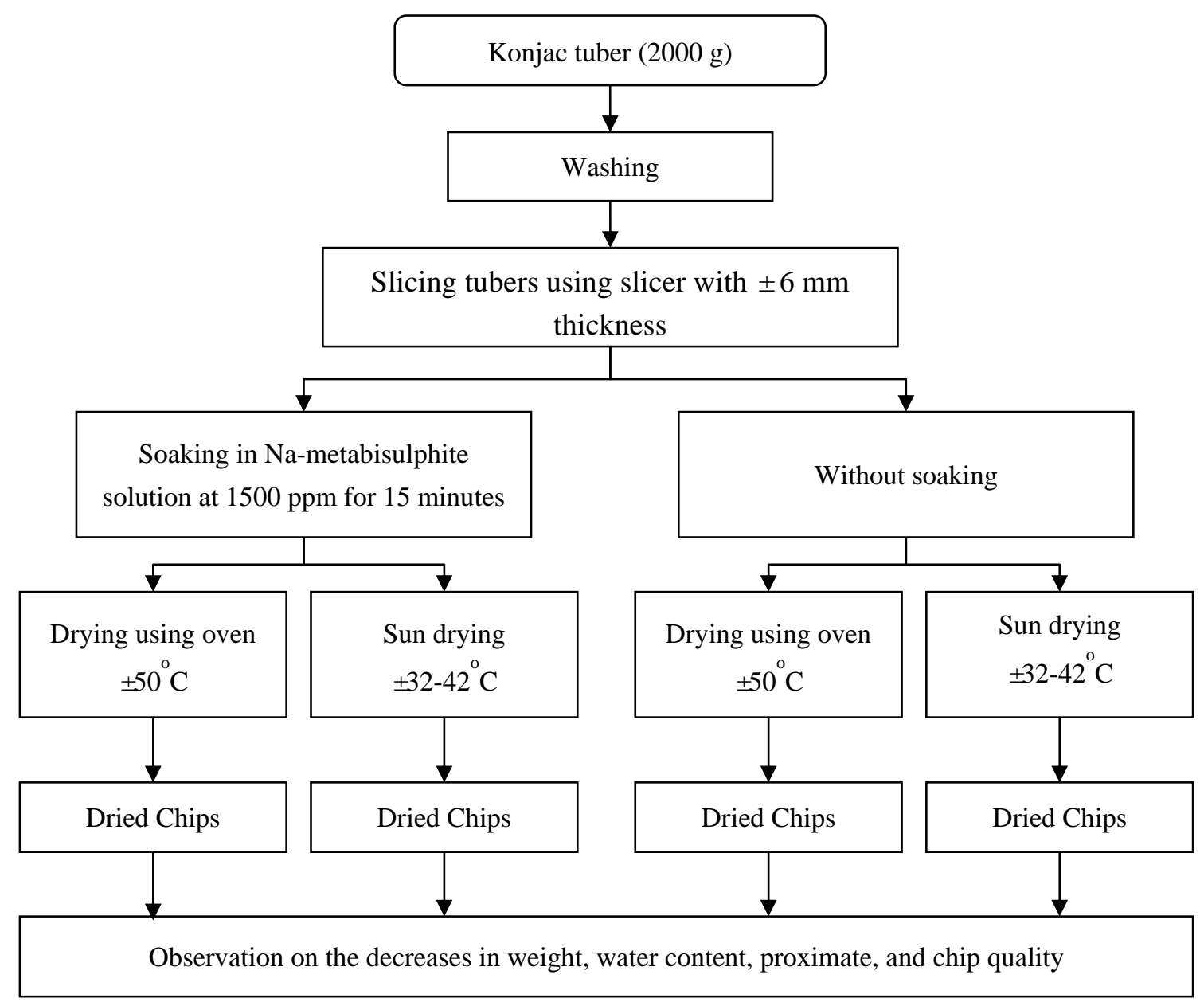

Figure 2. Flowchart of the drying method

\subsection{Experimental Design}

The experimental design used in drying process was a completely randomized design (CRD) with two factors. The first factor is soaking treatment which consists of two levels, namely (i) soaking in sodium metabisulphite solution at $1500 \mathrm{ppm}$ for 15 minutes and (ii) without soaking. The importance of this solution was the attrativeresearch topic such as discussed in (Slattery, 2019), (Buckman et al., 2015) and (Maathumai et al., 2018). The second factor is the drying method which consists of two levels, namely sun drying (SD) and oven drying (OD). Accordingly, this research involves four treatments, i.e., without soaking-sun drying (WSSD), soaking-sun drying (SSD), without soaking-oven drying (WSOD), and soaking-oven drying (SOD). Every treatment was replicated three times. Therefore, the experimental design model is as in (1).

$$
Y_{i j k}=\mu+A_{i}+B_{j}+(A B)_{i j}+\varepsilon_{i j k}
$$

where

$A \quad=$ effect of soaking and non-soaking treatment

$B \quad=$ effect of drying treatment

$Y_{i j k}=$ observed value at $i$-level of $A$-factor and $j$-level of $B$-factor and the $k$-th replication

$\mu \quad=$ overall mean

$A_{i} \quad=$ effect of $A$-factor at $i$-level

$B_{j} \quad=$ effect of $B$-factor at $j$-level

$(A B)_{i j} \quad=$ interaction between factors $A$ at $i$-level and $B$ at $j$-level

$\varepsilon_{i j k}=$ effect of error resulted from factors $A$ at $i$-level and $B$ at $j$-level at the $k$-th replication

The study of this model typically starts with a homogeneity test by calculating the coefficient of variation of the model. If the value of coefficient of variation is less than $25 \%$, we say that the residual variance of the model is 
homogenous. Conversely, if the value of coefficient of variation is more than $25 \%$, the residual variance of the model is not homogenous. The formula of coefficient of variation is as in (2).

$$
C V=\frac{\widehat{\sigma}}{\bar{Y}} \times 100 \%
$$

where :

$$
\begin{aligned}
& C V=\text { sample coefficient of variation } \\
& \hat{\sigma}^{2}=\text { sample variance of error term } \\
& \bar{Y} \quad=\text { overall mean sample }
\end{aligned}
$$

\section{Results and Discussion}

\subsection{Characteristics of Dried Chips Produced from Preliminary Experiment}

To make a comparison, in this paragraph we report the characteristics of IK dried chips produced by local farmers (SD) and those produced from laboratory experiment (OD). As mentioned earlier, these characteristics consist of eleven components. They are described in the second column of Table 2. All components are measured in \% except TPC in log cfu/g. In this experiment, the period of SD is 48 hours and that of OD is 36 hours.

Table 2. Characeristics of IK chips produced fromSD and OD

\begin{tabular}{clrrc}
\hline No. & Component & SD & OD & Difference* $^{*}$ \\
\hline 1 & Moisture & 12.37 & 10.39 & $\mathrm{~S}$ \\
2 & Glucomannan & 34.36 & 37.57 & $\mathrm{~S}$ \\
3 & Ca-oxalate & 0.95 & 0.89 & $\mathrm{~S}$ \\
4 & Whiteness & 23.36 & 25.53 & $\mathrm{~S}$ \\
5 & Ash & 6.26 & 6.37 & $\mathrm{~S}$ \\
6 & Fiber & 9.97 & 10.04 & $\mathrm{~S}$ \\
7 & Fat & 0.52 & 0.57 & $\mathrm{~S}$ \\
8 & Protein & 5.10 & 5.12 & $\mathrm{NS}$ \\
9 & Starch & 27.02 & 24.96 & $\mathrm{~S}$ \\
10 & TPC (log cfu/g) & 4.67 & 3.43 & $\mathrm{~S}$ \\
11 & $\mathrm{SO}_{2}$ Residue & 0.13 & 0.16 & $\mathrm{~S}$ \\
\hline
\end{tabular}

\section{* S: significant; NS: not significant}

This table shows that dried chips produced from laboratory have better quality except in protein content (there is no significant difference between SD and OD). Furthermore, the drying process in laboratory requires a shorter period of time to reduce the chips' water content to less than $12 \%$ (required by Indonesian National Standard number: 01-1680-1989). It takes 36 hours, while that performed in the field takes 48 hours. This difference of quality is especially due to the environment condition and the difference between the thickness of chips used in laboratory and that used in the field. In general, from Table 1 we learn that;

1. Moisture content issued from OD is less than that from SD. It depends on water level content. Higher water level could facilitate the growth of fungi which may blacken the color of the chips and reduce the degree of whiteness. Our experiment shows that OD reduces significantly the moisture content.

2. Glucomannan content produced from SD is lower than that from OD since the chips used in field practice are obtained from plants with different ages and from tubers which are not immediately processed. This is in line with (Ohtsuki, 1968) who has remarked that glucomannan content and level are influenced by plant variety, plant age, and time interval between tuber harvesting and processing.

3. Calcium oxalate content issued from OD is less than that given by SD with a small difference. This is because it is derived from the same plant variety and growth place. This component is usually contained in tubers, stems, leaves, flowers, and seeds (Dwiyono et al., 2014). As mentioned in Indriyani (2011), its amount in IK plants is influenced by age, stage of growth, season, nutrients, and growth place.

4. The whiteness level produced from SD is lower than that from OD. This suggests that the variety of slice thickness and water content affect the level of whiteness. 
5. Ash and fiber content of chips from field practice and laboratory are considerably different. This is due to the plant age, growth place, and nutrient content in the surrounding area (Indriyani, 2011).

6. Fat content is also influenced by drying method while proteinis not.

7. Starch content and TPC microorganism content are significantly reduced by OD method.

8. Finally, $\mathrm{SO} 2$ residue is significantly increased by OD method.

\subsection{Drying Method}

Drying treatment is one of the preservation methods for agriculture products which can be conducted by various means such as the sun (natural source) and oven (man made technology). The drying rates (in $\mathrm{g} \mathrm{H}_{2} \mathrm{O} /$ hours) resulted from our experiment for different drying methods are shown numerically in Table 3 and visually in Figure 3. It shows that, WSOD produces a higher drying rate than the other treatments since, in general, OD produces more continuous heat and higher temperatures than SD.

In our experiment, for different treatment, the initial moisture content of wet chips are used. It is $87.97 \%$ wet-basic (wb) for SSD, 84.97\% wb for WSOD, 87.69\% wb for SOD, and 84.97\% for WSOD. After 36 hours of drying, moisture content decreases up to $4.55 \% \mathrm{wb}$ for SSD, $4.59 \%$ wb for WSSD, $5.5 \% \mathrm{wb}$ for SOD, and 3.14\% $\mathrm{wb}$ for WSOD. Thus, we see that WSOD treatment has the highest drying rate. This result is most probably due to higher oven temperature $\left(50{ }^{\circ} \mathrm{C}\right)$ compared to sun temperature $\left(32^{\circ}-42^{\circ} \mathrm{C}\right)$ and to lower initial moisture content. In this regards, (Arslan \& Musa Özcan, 2010) who have compared the drying rate of IK chips with that of onion, stated that the drying process of onion slices using oven at a temperature of $50{ }^{\circ} \mathrm{C}$ takes 15 hours to reach $36.68 \% \mathrm{wb}$ moisture content. Meanwhile, according to them, to reach $48.86 \%$ wb moisture content, SD method takes 17 hours. This longer time is also due to temperature fluctuation during drying process.

Table 3. Drying rate as function of drying time $T$ (in hours)

\begin{tabular}{|c|c|c|c|c|c|}
\hline \multirow{2}{*}{ Phase } & \multirow{2}{*}{$T$} & \multicolumn{4}{|c|}{ Treatment } \\
\hline & & WSOD & WSSD & SOD & SSD \\
\hline \multirow[t]{7}{*}{1} & 0 & 0.00 & 0.00 & 0.00 & 0.00 \\
\hline & 1 & -0.78 & -0.84 & -0.86 & -0.82 \\
\hline & 2 & -1.33 & -1.31 & -1.57 & -1.33 \\
\hline & 3 & -1.80 & -1.67 & -1.98 & -1.70 \\
\hline & 4 & -2.19 & -2.03 & -2.44 & -2.06 \\
\hline & 5 & -2.53 & -2.36 & -2.82 & -2.40 \\
\hline & 6 & -2.88 & -2.52 & -3.15 & -2.57 \\
\hline \multirow[t]{4}{*}{2} & 6 & -2.88 & -2.52 & -3.15 & -2.57 \\
\hline & 8 & -3.80 & -2.85 & -3.81 & -2.85 \\
\hline & 10 & -4.51 & -3.23 & -4.31 & -3.31 \\
\hline & 12 & -4.84 & -3.57 & -4.53 & -3.91 \\
\hline \multirow[t]{7}{*}{3} & 12 & -4.84 & -3.57 & -4.53 & -3.91 \\
\hline & 16 & -5.00 & -3.90 & -4.67 & -4.40 \\
\hline & 20 & -5.09 & -4.17 & -4.72 & -4.60 \\
\hline & 24 & -5.11 & -4.38 & -4.75 & -4.87 \\
\hline & 28 & -5.14 & -4.58 & -4.77 & -4.92 \\
\hline & 32 & -5.15 & -4.74 & -4.78 & -4.96 \\
\hline & 36 & -5.16 & -4.76 & -4.80 & -5.00 \\
\hline
\end{tabular}

In this table, Phase 1 is the most rapid phase which occurs at the beginning of drying process while Phase 2 is a slower phase and Phase 3 is the slowest phase which occurs at the end of drying process. Phase 3 is asymptotic; the larger the value of $T$ the drying rate never reaches but tends to the horizontal line $(T)$. This is evident as the moisture content of agricultural products could not reach $0 \%$. 
In practice, Phase 1 refers to the fastest period, i.e. from 0 to 6 hours. Phase 2 is from 6 to 12 hours and Phase 3 is starts from 12 hours to 36 hours (for OD) or 48 hours (for SD).

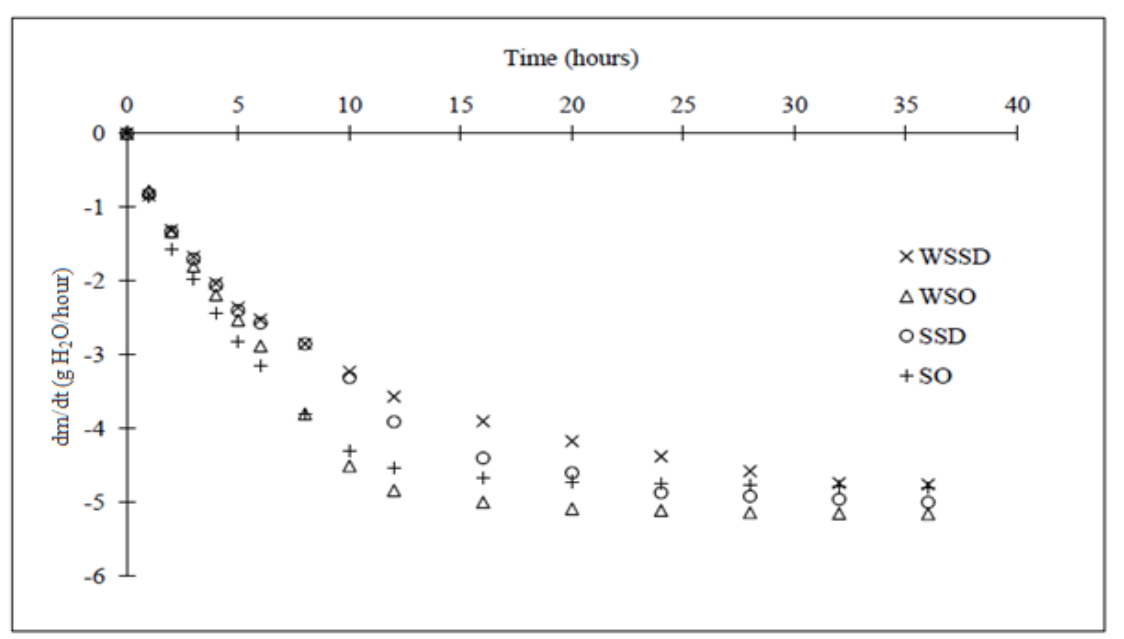

Figure 3. Scatter plot of drying rate versus drying period for all treatments

Figure 3 clearly shows that WSOD treatment produces a higher drying rate of amount 0.46 than the other treatments. This amount is represented in the regression equation given in the first line and second column of Table 4. In this table, we present the relationship between drying rate $(Y)$ and drying time $(T)$ for each phase and each drying method.

Table 4. Relationship between drying rate $(Y)$ and drying time $(T)$

\begin{tabular}{ccccc}
\hline \multirow{2}{*}{ Phase } & \multicolumn{4}{c}{ Treatment } \\
\cline { 2 - 5 } & WSOD & WSSD & SOD & SSD \\
\hline 1 & $Y=-0.46 T-0.25$ & $Y=-0.40 T-0.32$ & $Y=-0.51 T-0.31$ & $Y=-0.41 T-0.31$ \\
2 & $Y=-0.33 T-1.04$ & $Y=-0.18 T-1.45$ & $Y=-0.23 T-1.86$ & $Y=-0.22 T-1.14$ \\
3 & $Y=-0.01 T-4.79$ & $Y=-0.05 T-3.09$ & $Y=-0.01 T-4.49$ & $Y=-0.04 T-3.66$
\end{tabular}

As an example, in Figure 4 we present the regression equation for each phase issued from WSSD treatment. See the third column of Table 3 .

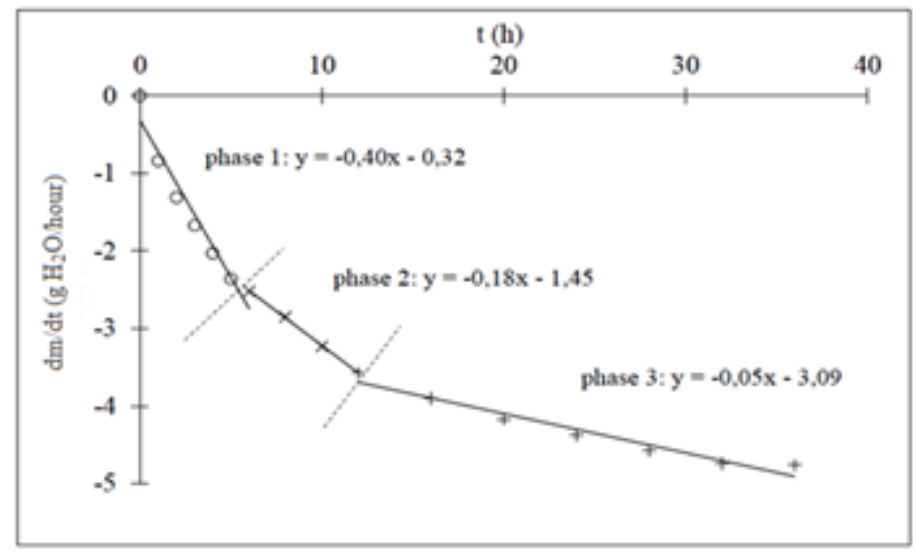

Figure 4. Regression equation for each phase issued from WSSD treatment

Figure 4 shows that under WSSD, Phase 1 produces the highest drying rate at $0.40 \mathrm{~g} \mathrm{H}_{2} \mathrm{O} /$ hour, while second phase $0.18 \mathrm{~g} \mathrm{H}_{2} \mathrm{O}$ /hour and the third $0.05 \mathrm{~g} \mathrm{H}_{2} \mathrm{O}$ /hour. Transition time between Phase 1 and Phase 2 is $\mathrm{t}_{1}=4.97$ (hour) while that between Phase 2 and Phase 3is $t_{2}=12.96$ (hour). During the initial drying period, the drying rate is at the highest level because the material is very responsive. In this period, evaporation energy or water bond is still low and increases as the drying period increases; this leads to a decrease in drying rate. In this 
regards, (Arslan \& Musa Özcan, 2010) have stated that the moisture content of a material is very high during initial drying experiment and this leads to a higher drying rate and diffusion.

The above results are about WSSD treatment. For the other treatments, the results are given in Table 5.

Table 5. Drying rate and transition time as function of treatments and phases

\begin{tabular}{ccccccccc}
\hline \multirow{2}{*}{$\begin{array}{c}\text { Drying } \\
\text { phase }\end{array}$} & \multicolumn{2}{c}{ WSOD } & \multicolumn{2}{c}{ WSSD } & \multicolumn{2}{c}{ SOD } & \multicolumn{2}{c}{ SSD } \\
\hline 1 & $\begin{array}{c}\text { Rate } \\
\left(\mathrm{g} \mathrm{H}_{2} \mathrm{O} / \mathrm{h}\right)\end{array}$ & $\begin{array}{c}\text { Time } \\
(\mathrm{h})\end{array}$ & $\begin{array}{c}\text { Rate } \\
\left(\mathrm{g} \mathrm{H}_{2} \mathrm{O} / \mathrm{h}\right)\end{array}$ & $\begin{array}{c}\text { Time } \\
(\mathrm{h})\end{array}$ & $\begin{array}{c}\text { Rate } \\
\left(\mathrm{g} \mathrm{H}_{2} \mathrm{O} / \mathrm{h}\right)\end{array}$ & $\begin{array}{c}\text { Time } \\
(\mathrm{h})\end{array}$ & $\begin{array}{c}\text { Rate } \\
\left(\mathrm{gH}_{2} \mathrm{O} / \mathrm{h}\right)\end{array}$ & $\begin{array}{c}\text { Time } \\
(\mathrm{h})\end{array}$ \\
\hline & 0.46 & $\mathrm{t}_{1}=5.86$ & 0.40 & $\mathrm{t}_{1}=4.97$ & 0.51 & $\mathrm{t}_{1}=5.64$ & 0.41 & $\mathrm{t}_{1}=$ \\
2 & & & & & & & & 4.38 \\
3 & 0.33 & $\mathrm{t}_{2}=11.78$ & 0.18 & $\mathrm{t}_{2}=12.96$ & 0.23 & $\mathrm{t}_{2}=11.76$ & 0.22 & $\mathrm{t}_{2}=13.80$ \\
& 0.01 & & 0.05 & & 0.01 & & 0.04 & \\
\hline
\end{tabular}

Table 5 shows that the drying phase and the drying treatment have influenced on drying rate. The highest drying rate was generated from the sodium metabisulphite SOD treatment, while the lowest drying rate was generated from the WSSD treatment. This could make sense because OD method provides more stable and continuous heat.

\subsection{Characteristics of Dried Chips Produced from Our Designed Experiment}

The characteristics of IK dried chips resulted from different drying methods with or without soaking in sodium metabisulphite solution are presented in Table 6 .

Table 6. Chemical parameters of IK dried chips issued from all treatments

\begin{tabular}{|c|c|c|c|c|c|c|}
\hline No. & Component & SOD & WSOD & SSD & WSSD & Difference* \\
\hline 1 & Moisture & 9.63 & 9.36 & 10.69 & 10.39 & $\mathrm{~S}$ \\
\hline 2 & Glucomannan & 48.16 & 45.25 & 38.81 & 37.57 & S \\
\hline 3 & Ca-oxalat & 0.83 & 0.89 & 0.84 & 0.95 & $\mathrm{~S}$ \\
\hline 4 & Whiteness & 34.29 & 30.44 & 31.85 & 25.53 & S \\
\hline 5 & Ash & 6.83 & 6.09 & 6.89 & 6.37 & $\mathrm{~S}$ \\
\hline 6 & Fiber & 9.03 & 9.23 & 10.08 & 10.04 & NS \\
\hline 7 & Fat & 0.52 & 0.52 & 0.66 & 0.57 & NS \\
\hline 8 & Protein & 6.19 & 6.25 & 6.05 & 5.12 & NS \\
\hline 9 & Starch & 29.66 & 23.34 & 30.16 & 24.96 & S \\
\hline 10 & TPC (log cfu/g) & 3.21 & 3.43 & 3.38 & 4.67 & S \\
\hline 11 & $\mathrm{SO}_{2}$ Residue & 0.42 & 0.16 & 0.32 & 0.13 & $\mathrm{~S}$ \\
\hline
\end{tabular}

\footnotetext{
* S: significant; NS: not significant
}

This table shows that the decrease of water content is significantly affected by drying method. The shortest period of time for reaching a certain level of water content is achieved by SOD treatment. This suggests that the standard water content, i.e. 12\% (as required by Indonesian National Standard, 1989, 01-1680-1989) can be achieved using OD method. According to Pornpraipech et al. (2017), the safe water content for the growth of mold or microorganisms is below $12 \%$. Regarding the whiteness, the highest degree is also produced by SOD, while the lowest is by WSSD. See Figure 6 for visual difference of IK dried chips produced from other treatments.

Similar remarks on the whiteness issue can be found in (Kumoro \& Hidayat, 2018). In their work, sodium metabisulphite was used on durian seed flour at a concentration of $600 \mathrm{ppm}$ and temperature of $50{ }^{\circ} \mathrm{C}$. These authors have increased the whiteness level from $57.70 \%$ (control) to $59.09 \%$. This shows how effective sodium metabisulphite in increasing the whiteness level of durian seed flour. We can also see in (Haryani, 2017) how effective that solution in increasing the whiteness level of porang flour. 


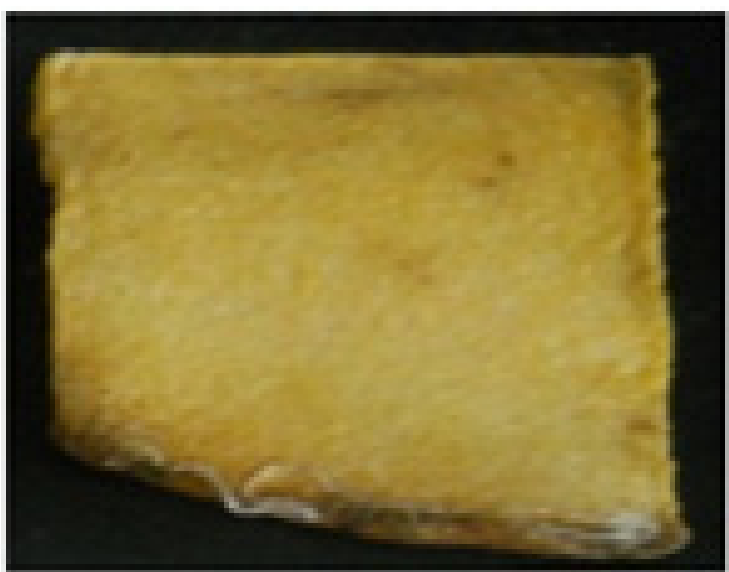

(A)

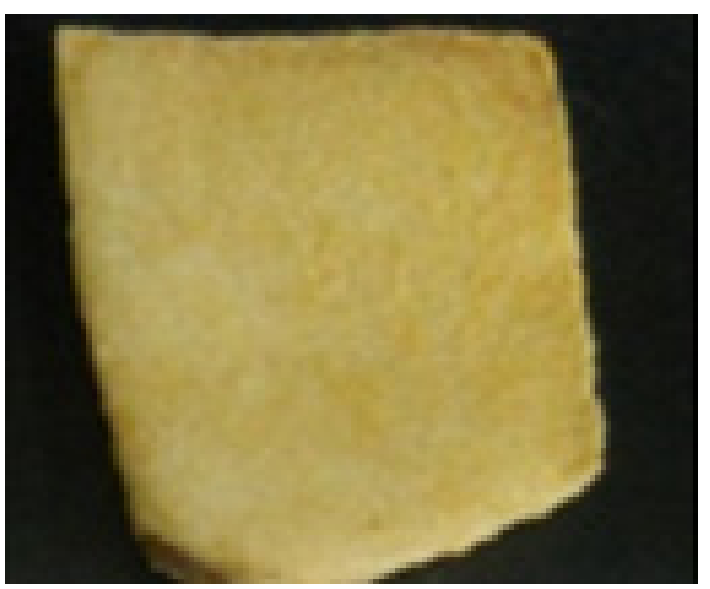

(C)

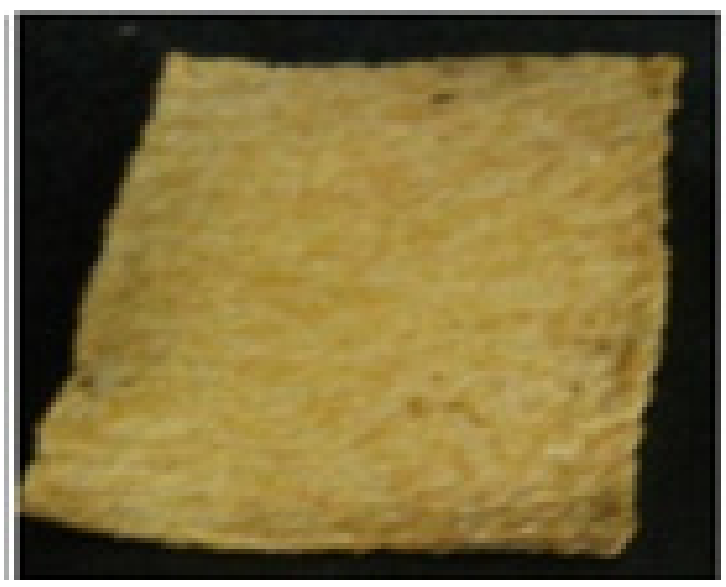

(B)

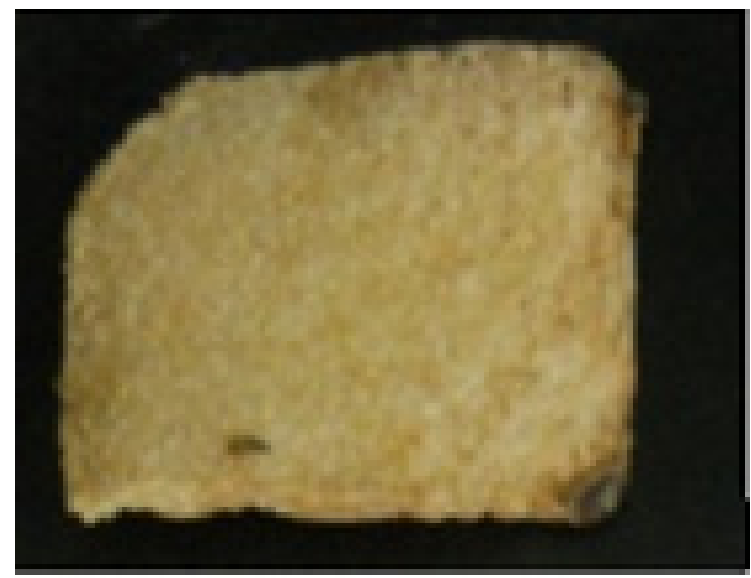

(D)

Figure 5. IK dried chips issued from WSOD (A), SSD (B), SOD (C), and WSSD (D)

This figure illustrate that the whiteness level issue from SOD is the highest. It is followed consecutively by SSD, WSOD and WSSD. This shows the influence of soaking treatment in increasing that level.

In general, Table 6 summarizes the chemical parameters of the eleven components which represent the quality of IK dried chips. If in Table 2 these parameters are studied in relation with SD and OD treatmens, Table 6 gives the value of these parameters for all four treatments SSD, SOD, WSSD, and WSOD. The first nine parameters are measured in $\%$ and the last in $\log \mathrm{cfu} / \mathrm{g}$. From that table, we learn that;

1. The highest content of glucomannan is reached by SOD treatment, while the lowest is found in the WSSD treatment. When SOD treatment is used, one thing must be underlined; according to (Ohtsuki, 1968), glucomannan content is influenced by plant variety, plant age, and interval time between tuber harvesting and post-harvesting processing.

2. The highest ash content is found in SSD treatment, while the lowest is in the WSSD treatment. Interestingly, this result is not only for IK but also for durian seed (Kumoro \& Hidayat, 2018) and sweet potato (Ahmed et al, 2010). As mentioned in (Mader et al, 1998), ash content is influenced by the type of material, ashing method, time, and ashing temperature.

3. The use of sodium metabisulphite affects $\mathrm{SO}_{2}$ residue while the drying process does not. Soaking treatment resulted in higher $\mathrm{SO}_{2}$ residue than that without soaking treatment. This is because sodium metabisulphite released sulphur bond and reacted with water, which then produced $\mathrm{SO}_{2}$. However, the treatment without soaking still results in a small amount in $\mathrm{SO}_{2}$. This amount is formed from $\mathrm{S}$ element in the material and S-H groups breaking in protein bond. 
4. The lowest rate of calcium oxalate is generated from SOD while the highest rate is generated from WSSD. As mentioned earlier, we learn from the literature that at high concentration, calcium oxalate can be harmful to human health because it may trigger irritation and kidney stone disease.

5. The growth of bacterial colonies or total plate colony (TPC) contained in IK flour is significantly influenced by the use of sodium metabisulphite which could suppress the growth of bacterial colonies.

\section{Concluding Remarks}

This paper deals with a new method to improve the quality of IK chips. It consists of slicing process to have homogenous thickness of chips, soaking treatment in pre-drying process, and drying process. According to our experiment, we found that SOD method at a temperature of $50^{\circ} \mathrm{C}$ during 36 hours gives the best results. The second best is SSD. This shows that soaking treatment has improve the quality of IK chips. More speifically, soaking in sodium metabisulphite solution at a concentration $1500 \mathrm{ppm}$ for 15 minutes could improve the quality of IK dried chips in terms of all parameters (moisture content, glucomannan content, calcium oxalate content, degree of whiteness, ash, fiber, fat, starch, $\mathrm{SO}_{2}$ residue, and TPC) except fiber, fat and protein. For these tree last parameers, OD and SD have no significant difference.

\section{Acknowledgements}

The authors are very grateful to the Editor and anonymous referees for their comments and suggestions that led to the final presentation of this paper. The authors also thank to Ministry of Research, Technology and Higher Eduacation of the Republic of Indonesia, for their sponsordhip. Special thanks go to Universitas Nasional, Bogor Agricultural University, Institut Pendidikan Indonesia and Universitas Negeri Jakarta, for providing research facilities. The authors are in debt to Prof. Ono Suparno and Dr. Liesbetini Haditjaroko at Bogor Agriculture University, for fruitful discussions.

\section{References}

Adegunwa, M.O., Alamu ,E.O., \& Omitogun, L. A. (2011). Effect of processing on nutritional contents of yam and cocoyam tubers. J. Appl. Biosci, 46, 3086- 3092.

Ahmed, M., Akter, M. S., \& Eun, J.-B. (2010). Peeling, drying temperatures, and sulphite-treatment affect physicochemical properties and nutritional quality of sweet potato flour. Food Chemistry, 121(1), 112-118. https://doi.org/10.1016/J.FOODCHEM.2009.12.015

Ahn, J. Y., Kong, C., \& Kim, B. G. (2014). Comparison of Oven-drying Methods for Determination of Moisture Content in Feed Ingredients Comparison of Oven-drying Methods for Determination of Moisture Content in Feed Ingredients, (November). https://doi.org/10.5713/ajas.2014.14305

Arslan, D., \& Musa Özcan, M. (2010). Study the effect of sun, oven and microwave drying on quality of onion slices. LWT - Food Science and Technology, 43(7), 1121-1127. https://doi.org/10.1016/J.LWT.2010.02.019

Bo, S., Muschin, T., Kanamoto, T., Nakashima, H., \& Yoshida, T. (2013). Sulfation and biological activities of konjac glucomannan. Carbohydrate Polymers, 94(2), 899-903. https://doi.org/10.1016/J.Carbpol.2013.01.049

Brugger, S. D., Baumberger, C., Jost, M., Jenni, W., \& Brugger, U. (2012). Automated Counting of Bacterial Colony Forming Units on Agar Plates, 7(3), 1-6. https://doi.org/10.1371/journal.pone.0033695

Buckman, E. S., Plahar, W. A., Oduro, I. N., \& Carey, E. E. (2015). Effects of Sodium Metabisulphite and Blanching Pretreatments on the Quality Characteristics of Yam Bean ( Pachyrhizus erosus ) Flour, 6(2), 138-144. https://doi.org/10.9734/Bjast/2015/14773

Carneiro, J. S., Nogueira, R. M., \& Martins, M. A. (2018). The oven-drying method for determination of water content in Brazil nut. Biosci.. J., Uberlandia, 34(3), 595-602. https://doi.org/10.14393/BJ-v34n3a2018-37726

Chouicha, S., Boubekri, A., Mennouche, D., \& Berrbeuh, M. H. (2013). Solar Drying of Sliced Potatoes . An Experimental Investigation. Energy Procedia, 36(August 2014), 1276-1285. https://doi.org/10.1016/j.egypro.2013.07.144

Doymaz, İ. (2008). Influence of blanching and slice thickness on drying characteristics of leek slices. Chemical Engineering and Processing: Process Intensification, 47(1), 41-47. https://doi.org/10.1016/J.Cep.2007.09.002

Dwiyono, K., Sunarti, T. C., Suparno, O., \& Haditjaroko, L. (2014). Penanganan Pascapanen Umbi Iles-iles 
(Amorphophallus muelleri Blume) Studi Kasus di Madiun, Jawa Timur. J Tek Ind Pert, 34(3), 179-188.

Hang, D. Z., Ang, Q. W., \& Eorge, S. S. G. (2010). Mechanism of Staggered Multiple Seedling Production from Amorphophallus bulbifer and Amorphophallus muelleri and its Application to Cultivation in Southeast Asia, 4, 84-90.

Haryani, K. (2017). Porang Flour (Amorphophallus Onchophyllus) Bleaching Process Using Natrium Metabisulfit and Ascorbic Acid. International Journal of Innovative Research in Advanced Engineering, 10(4), 2349-2163. https://doi.org/10.26562/IJIRAE.2017.SPAE10090

Indryani, S. (2011). A model of relationship between climate and soil factors related to oxalate content in porang (Amorphophallus muelleri Blume) corm. Biodiversitas, Journal of Biological Diversity, 12(1), $45-51$. https://doi.org/10.13057/biodiv/d120109

Jansen, P. C. M., \& Hetterscheid, W. (1996). Amorphophallus Blume ex Decaisne. In: Plant Resources of South-East Asia 9. Plants yielding non-seed carbohydrates, M. Flach, F. Rumawas (eds.). Backhuys Publ., Leiden (1996) 45-50.

Kumoro, A., \& Hidayat, J. (2018). Effect of soaking time in sodium metabisulfite solution on the physicochemical and functional properties of durian seed flour. MATEC Web of Conferences, 156. https://doi.org/10.1051/matecconf/201815601028

Mader, P., Száková, J., \& Miholová, D. (1998). Classical dry ashing of biological and agricultural materials. Part II. Losses of analytes due to their retention in an insoluble residue. Analusis, 26(3), 121-129. https://doi.org/10.1051/analusis:1998121

Nizamani, F. G., Buriro, M., Khokhar, A., \& Nizamani, M. M. (2019). Effect of Drying Methods and Storage Periods on Wheat ( Triticum aestivum L .) Quality Parameters, (March). https://doi.org/10.17485/ijst/2019/v12i12/141812

Ohtsuki, T. (1968). Studies on reserve carbohydrates of four Amorphophallus species, with special reference to mannan. Bot. Mag. Tokyo, 81, 119-126. Retrieved from http:/ci.nii.ac.jp/naid/10024069409/en/

Oke, M. O., \& Bolarinwa, I. F. (2012). Effect of Fermentation on Physicochemical Properties and Oxalate Content of Cocoyam ( Colocasia esculenta ) Flour. ISRN Agronomy, 2012, 1-4. https://doi.org/10.5402/2012/978709

Pornpraipech, P., Khusakul, M., Singklin, R., Sarabhorn, P., \& Areeprasert, C. (2018). Effect of temperature and shape on drying performance of cassava chips, 51(2017), 402-409.

S.Maathumai, B.Anuluxshy, W.A.J.P Wijesinghe, S.M.I.P.G. Bandara, S. S. (2018). Effect of Sodium Metabisulphite on the Nutritional Characteristics of Palmyra Effect of Sodium Metabisulphite on the Nutritional Characteristics of Palmyra Fruit Pulp, (August 2019). https://doi.org/10.9790/2402-1202015962

Santos, C., José, A., Queiroz, D. M., Maria, R., \& Figueirêdo, F. De. (2015). Sun drying of residual annatto seed powder Acta Scientiarum Sun drying of residual annatto seed powder, (January). https://doi.org/10.4025/actascitechnol.v37i1.20582

Slattery, S. (2019). Alternatives to sodium metabisulphite for blackspot prevention in prawns, (August).

Wardhani, D. H., Aryanti, N., Haryani, K., \& Maharani, F. (2017). Kinetic study of solid fermentation of Amorphophallus oncophyllus flour using Aspergillus niger And Its Prebiotic potential. Carpathian Journal of Food Science and Technology, 9(2), 43-56.

\section{Copyrights}

Copyright for this article is retained by the author(s), with first publication rights granted to the journal.

This is an open-access article distributed under the terms and conditions of the Creative Commons Attribution license (http://creativecommons.org/licenses/by/4.0/). 